\title{
Production Equipment Development Needs for a 700 Metric Ton/Year Light Water Reactor Mixed Oxide Fuel Manufacturing Plant
}

by

D.E. Blahnik

September, 1977

Prepared for the Energy Research and Development Administration under Contract EY-76-C-06-1830 


\title{
NOTICE
}

This report was prepared as an account of work sponsored by the United States Government. Neither the United States nor the Department of Energy, nor any of their employees, nor any of their contractors. subcontractors, or their emoloyees, makes any warranty, express or implied, or assumes any legal liability or responsibility for the accuracy, completeness or usefuiness of any information, apparatus, product or process disclosed, or represents that its use would not iniringe privately owned rights.

The views, opinions and conclusions contained in this report are those of the contractor and do not necessarily represent those of the United States Government or the United States Department oi Energy.

\author{
PACIFIC NORTHWIEST LABORATORY \\ operated by \\ BATTELLE \\ for the \\ UNITED STATES DEPARTMENT OF ENERGY
}

Under Contract EY-76-C-06-1830

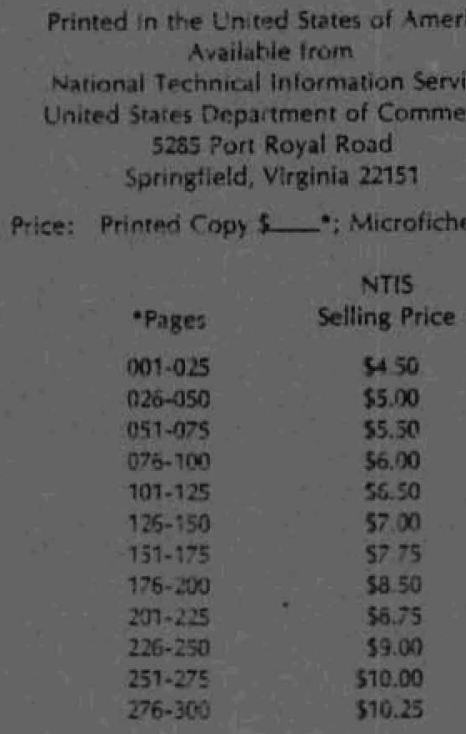




\section{8}

BNIVL-2414

UC -78

PRODUCTION EQUIPMENT DEVELOPMENT NEEDS FOR A 700 METRIC TON/YEAR LIGHT WATER REACTOR MIXED-OXIDE FUEL

MANUFACTURING PLANT

by

D. E. Blahnik

September, 1977

BATTELLE

Pacific Northwest Laboratories

Richland, Washington 99352 
,

. 


\section{ACKNOWLEDGEMENTS}

This report summarizes a study conducted by Battelle, Pacific Northwest Laboratories for the former Energy Research and Development Administration, the functions of which have now been transferred to the Department of Energy. The author acknowledges the contributions from personnel in the Fuels Design and Development Section, Materials Department, and from Wendell J. Bailey in particular. We also appreciate the assistance provided by participants who responded to our survey. 


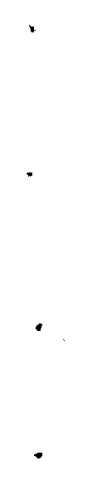

.

. 
We conducted a literature search and survey of fuel suppliers to determine how much development of production equipment is needed for a 700 metric tons/yr light water reactor (LINR) mixed-oxide uranium dioxideplutonium dioxide $\left(\mathrm{UO}_{2}-\mathrm{PuO}_{2}\right)$ fuel fabrication plant. This work was performed for the Savannah River Laboratory. Savannah River Laboratory is developing a conceptual design and a design criteria for a plant in this size range for the Department of Energy.

The results of the study indicate that moderate to major production equipment development is needed in the powder and pellet processing areas. The equipment in the rod and assembly processing areas need only minor development effort. A summary is provided in Figure 1 of equipment development requirements.

Required equipment development for a $700 \mathrm{MT} / \mathrm{yr}$ plant is not anticipated to delay startup of the plant. The development, whether major or minor, can be done well within the time frame for licensing and construction of the plant as long as conventional production equipment is used.

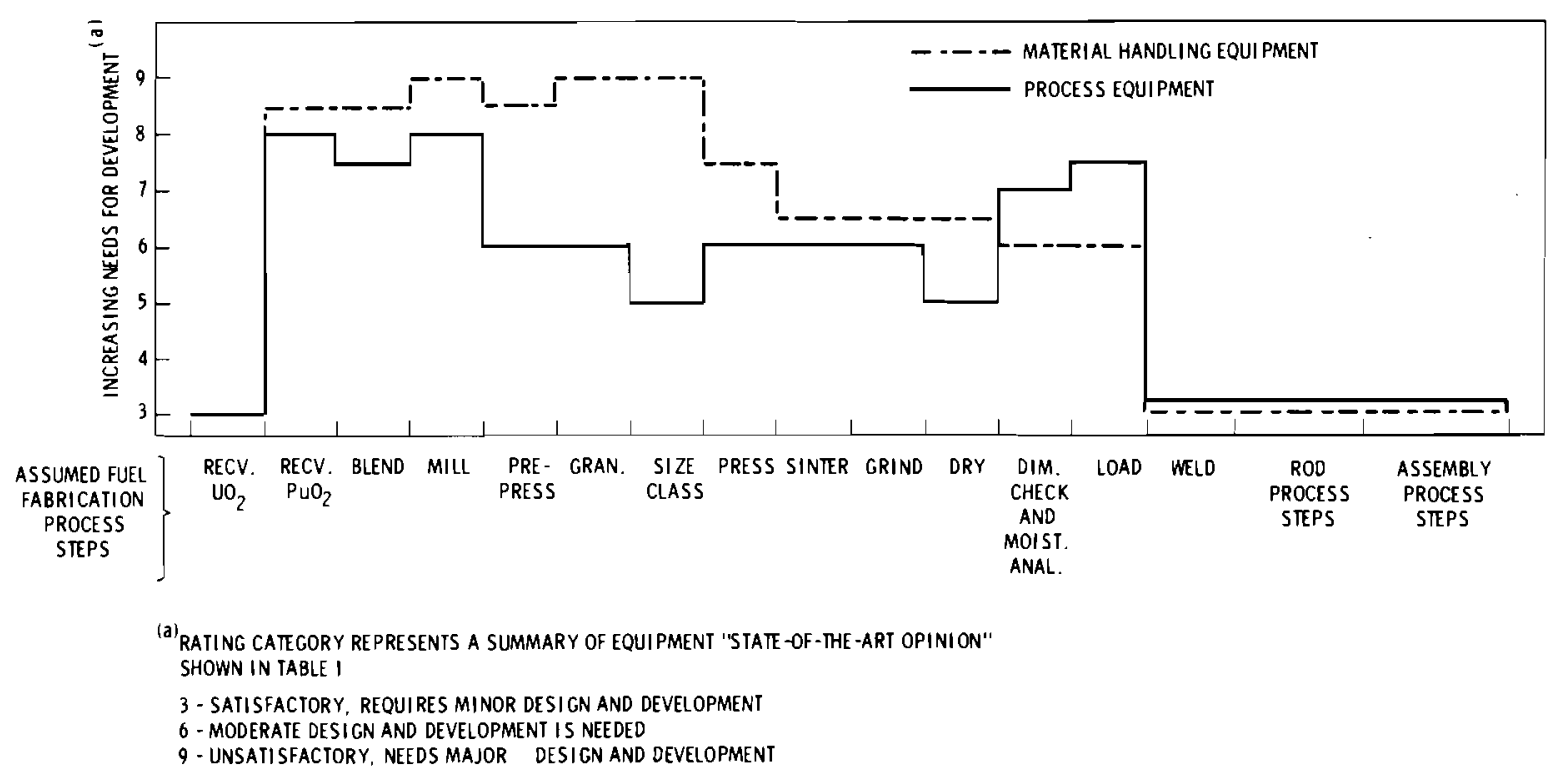

FIGURE 1. MOX Fuel Fabrication Equipment Development Requirements Summary 

SUMMARY ............................ . . v

INTRODUCTION . . . . . . . . . . . . . . . . . . . . 1

CONCLUSIONS AND RECOMMENDATIONS . . . . . . . . . . . . . . 3

STUDY DESCRIPTION . . . . . . . . . . . . . . . . . . . . 7

Literature Search . . . . . . . . . . . . . . 7

Fuel Supplier Survey . . . . . . . . . . . . . . 8

Fuel Fabrication Plant Description . . . . . . . . . 9

EQUIPMENT DEVELOPMENT REQUIREMENTS . . . . . . . . . . . . . 11

Equipment Functionability ............... 11

Process Equipment Functionability .. . . . . . . 11

Materials Handling Equipment Functionability . . . . . 12

Equipment Maintainability ............. 12

Process Equipment Maintainability ......... 12

Materials Handling Equipment Maintainability . . . . . 12

Equipment Cleanup and Replacement . . . . . . . . . 13

Process Equipment Cleanup and Replacement . . . . . 13

Materials Handling Equipment Cleanup and Replacement . . 13

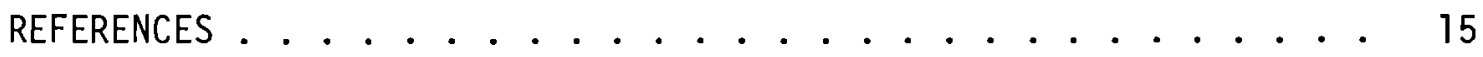

BIBLIOGRAPHY . . . . . . . . . . . . . . . . . 17

APPENDIX A - QUESTIONNAIRE FOR FUEL SUPPLIER SURVEY . • . • • 21 



\section{INTRODUCTION}

Mixed-oxide (MOX) fuel production over the past 20 years has been limited to small-scale volumes. The majority of MOX fuel in the U.S. has been fabricated in laboratories and pilot plants using batch-type equipment and manual operations. The current annual production capacity of MOX fuel fabrication in the U.S. is estimated at 50 to 75 metric tons (MT). The largest plant in the world is probably the Belgonucleaire Plant, in Belgium, which can manufacture about 50 MT of MOX fuel per year. Therefore, a $700 \mathrm{MT} / \mathrm{yr}$ plant represents a substantial capacity scaleup over current plants.

This report summarizes the results from a study to evaluate the LWR MOX fabrication production equipment development needs. The evaluation is a result of a literature search and a general survey of nuclear fuel fabricators. We assumed that the equipment would be used in a hypothetical plant designed to manufacture 700 MT MOX fuel per year and would be capable of producing both pressurized water reactor (PWR) and boiling water reactor (BWR) fuels. We also assumed a MOX fuel fabrication process and determined which types of equipment and operations are preferred for a large plant before evaluating the state-of-the-art of the equipment. This was necessary since most of the past experience has been in small plants with batch-type equipment and manual handling.

The production equipment of concern in this study are both the process and materials handling equipment. The process equipment would include the major equipment items (e.g., powder blender, pellet sintering furnace, end cap welder, etc.) but not the ancillary items (e.g., gas supply, exhaust system, shielding, etc.). The materials handling equipment would include the in-line conveyors, index and feed mechanisms, storage bins, etc., that are used to move and store the fuel materials in the process. 
. 


\section{CONCLUS IONS AND RECOMMENDATIONS}

The results of this study indicate that moderate to major development is needed in the following areas:

- Process Equipment. Except for the rod load and decontamination steps the functional aspects of the equipment are fairly well developed through the entire process. However, substantial improvements are needed for equipment maintenance, cleanup, and replacement in the powder and pellet processing areas.

- Materials Handling Equipment. Substantial development is needed in the powder and pellet fabrication areas. It is important that mechanical transfer to and from equipment be done with a minimum of dust generation and pellet damage. Minimizing the spread of $\mathrm{PuO}_{2}$ and mixed oxide dust within the containment areas will be important to maintain strict accountability and minimal radiation levels.

The literature search and survey indicate that at the front end of the process (powder receiving through blending) process equipment should be batch type with semi-mechanized operations. Continuous process equipment with fully mechanized operations are preferred from powder milling through pellet drying. Batch and/or continuous equipment with semi-mechanized operations are recommended for pellet inspection, rod fabrication, assembly fabrication and packaging. Table 1 shows a breakdown of the equipment evaluation.

Comprehensive industrial engineering studies should be made to assure that each piece of production equipment is sized properly and interfaces with adjoining production equipment, auxiliary equipment, gloveboxes, and other production 1 ines in a systemmatic manner. The study reveals the difficulty of divorcing the evaluation of the process and materials handling equipment design from the rest of the plant facilities. An evaluation must consider plant operations as a whole: plutonium containment, criticality safety, shielding; waste, scrap, reject and rework streams; heating and ventilating, access control; accountability; etc. 


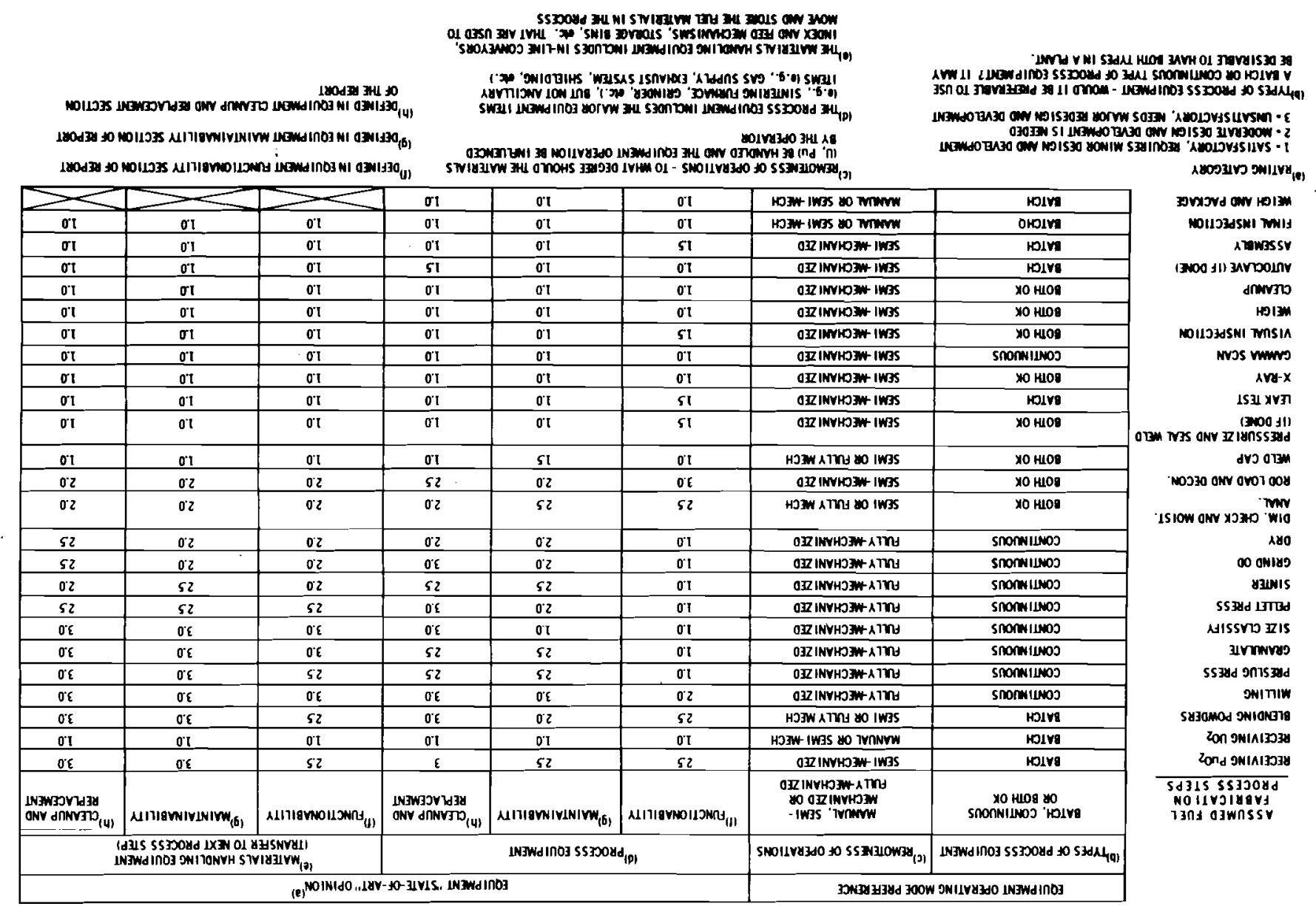

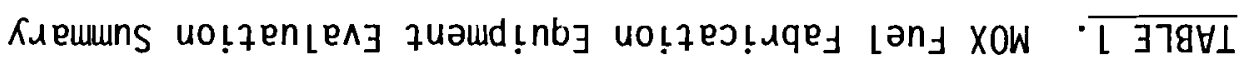


Personnel with extensive experience in MOX fuel fabrication, large ( $\geq 700 \mathrm{MT} / \mathrm{yr}$ ) $\mathrm{UO}_{2}$ fuel plant operations, and other ceramic industry operations should participate in the design, development, shakedown and operation of the plant. The equipment supplier, architect-engineer and operating company should maintain close collaboration. It is important to maintain continuity of the management team through the design, development, construction, shakedown and long-term operating and maintenance improvement phases of the project.

Developmental activities on some of the equipment identified in this report should start at least 3 years before installation in the plant. It would be desirable to cold test an entire production line of equipment before it is installed. The large scaleup in this plant will probably result in a one- to three-year shakedown and production efficiency improvement phase after the equipment is installed. In the first year, standin materials, and then depleted $\mathrm{UO}_{2}$, should be processed for initial shakedown before beginning MOX production. The more advanced the testing of equipment and the training of maintenance personnel before plant startup, the more efficient the shakedown and operation of the plant will be.

This study is a general evaluation of development needs for equipment. We recommend the following for more detailed analysis of the equipment development requirements.

- Define in detail the process to be used.

- Specify the types of feed materials (e.g., 1st, 2nd, 3rd or GESMO generation $\mathrm{Pu}$ ) and the batch sizes to be used.

- Determine the product mix to be manufactured by the plant (e.g., for BWR and/or PWR; 1st generation or 2nd generation reactors or $\mathrm{Pu}$ burners; enrichment, sizes, assembly mix) and volumes and schedules for each product.

- Determine if the full production capability must be installed at once or if it can be gradually built up.

- Define the regulatory criteria, especially the safeguards and shielding requirements, because they have a large impact upon the plant design. Criteria on effluents and waste are also important. 
- The equipment and plant design team should:

1) visit ${ }^{(a)}$ with current and past MOX fuel suppliers to determine if more detailed information on their equipment development experience and recommendations can be obtained, particularly in equipment areas identified to be lacking in this report

2) solicit(a) equipment manufacturers for their interest and information on equipment identified as needing the most development

3) visit large ( $\geq 700 \mathrm{MT} / \mathrm{yr}) \mathrm{UO}_{2}$ plants.

- Conduct industrial engineering studies to determine the best types and layouts of equipment to be used in the plant to meet the product specifications and throughput requirements on a longrange basis.

- Establish the equipment criteria.

The production equipment can be improved fairly rapidly if the equipment is developed according to a well-defined plan. The materials handling equipment, in particular, might be developed rapidly because opportunity exists for using ingenuity with a wide variety of conventional materials handling and storage equipment already on the market.

(a) Workshops may be the most time cost-effective way for accomplishing this type of work. 


\section{STUDY DESCRIPTION}

A literature search and general survey of nuclear fuel fabricators was made to determine the state-of-the-art of MoX fuel fabrication production equipment. The Bibliography lists the results of the literature survey. An effort to obtain more detailed information from fuel vendors was unsuccessful because they prefer to keep their process and equipment developmental work proprietary. We were also unable to visit fuel suppliers to obtain more detailed information and recommendations because of limited funding and lack of specific information about the product mix, feed materials, and process definition at the time of the survey.

\section{LITERATURE SEARCH}

An extensive literature search reveals very little public information on LWR facilities, and particularly LWR equipment. Most of the useful available information concerns liquid metal fast breeder reactor fuel facilities and fuel fabrication. The information available on equipment is primarily general and philosophical.

The most useful information on LWR fuel plants is in the GESMO (1) report and the Westinghouse Recycle Fuel Plant Docket. (2) The Westinghouse Docket has by far the most detailed information about production equipment. The Docket was comprehensive and, thus, was selected to represent the GESMO Model $\mathrm{Plant}$ in many respects.

Over a decade ago MOX fuel processes were developed, and studies (3) were made of facility designs, fuel fabrication costs, etc., for plants in the ton/day size range. General plant layouts and pictures of equipment appear in many of the references, especially the British reports. They have documented their experiences from start ${ }^{(4)}$ to finish $(5)(a)$ in their PFR fuel production campaign and have adopted a management approach that appears to work successfully for a MOX plant.

(a) Reference 5 should be required reading for MOX fuel plant designers. 
. 


\section{EQUIPMENT DEVELOPMENT REQUIREMENTS}

Equipment for a 700 MT/yr MOX fuel plant represents a scaleup of about 35 times the current largest plant in the U.S. and 14 times the world's largest plant. The state-of-the-art for a single-file production line size is about $50 \mathrm{MT} / \mathrm{yr}$. The proposed Westinghouse plant for Anderson, South Carolina was sized with $\sim 200$ MT/yr line using branch parallel lines where throughput demands made it necessary.

Equipment was evaluated in terms of functionability, maintainability, and cleanup and replacement (Table 1). Safety is considered an integral part of these characteristics.

\section{EQUIPMENT FUNCTIONABILITY}

When the MOX fuel production equipment is evaluated for how well it will perform its functions, the following questions were considered:

- Has this equipment demonstrated adequate performance in processing a high volume of $\mathrm{UO}_{2}$ fuels and/or pilot production runs of MOX fuels?

- Is the equipment highly reliable?

- Is the throughput capacity adequate for avoiding a large number of duplicate equipment items?

- Is the equipment adaptable to criticality safeguard requirements?

\section{Process Equipment Functionability}

The process equipment in the process assumed for this study is fairly well developed, primarily because of its use in $\mathrm{UO}_{2}$ fuel plants. Those steps in the process identified as needing the most improvement in this category are:

- receiving and storage system for $\mathrm{PuO}_{2}$ powder

- blending of mixed oxide powder

- quality assurance inspection and analysis of sintered pellets

- rod loading and decontamination. 
Materials Handling Equipment Functionability

Substantial developmental work will be needed to improve the materials handling and storage function throughout the powder and pellet processing steps. Shielding requirements have necessitated minor equipment development for semi-remote handling of rods and assemblies.

The powder area requires conveyor and storage systems that provide containment of MOX dust for accountability, process control, and minimization of radiation levels. The pickup of extraneous contaminants and potential for reducing powder homogeniety (after blending) must be avoided. It is important that loading and unloading of materials at each process equipment piece be accomplished with minimal dusting and pellet damage.

\section{EQUIPMENT MAINTAINABILITY}

When the MOX fuel production equipment is evaluated for ease of maintenance, the following questions were considered:

- Is the equipment designed with emphasis on preventive and minimal routine maintenance, rather than unscheduled maintenance?

- Are components accessible for easy and rapid changeout (substitution)?

- Can procedures be implemented to minimize radiation exposures to maintenance personnel?

- Is the use of organic materials in the equipment minimized?

Process Equipment Maintainability

Existing process equipment needs substantial maintenance improvements in the areas of powder and pellet processing. Those steps in greatest need of improvement are receiving $\mathrm{PuO}_{2}$, milling, preslugging, granulating, continuous sintering and pellet inspection.

Materials Handling Equipment Maintainability

Materials handling between all process steps prior to pellet grinding requires major design and development attention. Handling between peilet grinding and rod end cap welding requires moderate improvements. Maintenance of rod and assembly handling equipment should be relatively simple if rods and assemblies can be removed from the equipment when interna? maintenance is required. 


\section{EQUIPMENT CLEANUP AND REPLACEMENT}

When the equipment is evaluated for ease of cleanup, modification or replacement, the following questions were considered:

- Is the equipment readily adaptable for use in glovebox and/or remote operations?

- Can the equipment be controlled to minimize the introduction of undesirable impurities into the fuel?

- Can the equipment be kept clean to minimize personnel radiation exposure?

- Can the equipment be easily decontaminated, removed from the facility and replaced?

- Are major components modular for ease of replacement?

- What about ultimate disposal of discarded equipment and volume reduction of such waste?

\section{Process Equipment Cleanup and Replacement}

This category is very important because it may be the greatest single source of downtime over the history of an operating plant. Equipment improvements are needed to assure easier cleanup and replacement through the entire powder and pellet areas. Rod and assembly areas appear adequate. Equipment must have a minimum of cracks, voids, etc., in those areas where powder can accumulate and where it is hard to remove. Rapid removal and replacement require quick disconnects, modular components, procedures, etc., which preclude the spread of contamination and minimize radiation exposure to personnel.

Materials Handling Equipment Cleanup and Replacement

Design and development improvements are most needed in the powder processing area and slightly less in the pellet process area. Rod and assembly handling equipment are not likely to become contaminated, but they must be kept clean to maintain fuel assembly cleanliness requirements.

Criteria which apply to process equipment cleanup and replacement also apply to the materials handling equipment. 


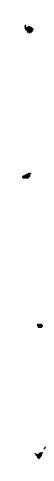




\section{REFERENCES}

1. Final Generic Environmental Statement on the Use of Recycle Plutonium in Mixed 0xide Fuel in Light Water Cooled Reactors (GESM0). NUREG0002 , Vol. 3, National Technical Information Service, Springfield, VA $22161,1976$.

2. Recycle Fuels Plant, License Application, AEC Docket No. 70-1432, Westinghouse Electric Corporation, Pittsburgh, PA, July 13, 1973.

3. J. B. Burnham, D. E. Deonigi, L. G. Merker, Comparative Costs of Oxide Fuel Elements. BNWL-273, Vols. 1-3, Battel1e, Pacific Northwest Laboratories, Richland, WA 99352, 1966.

4. S. E. Smith and P. A. White, "Process and Plant Development for a Large Scale Plutonium Fuel Element Manufacturing Facility". Proceedings of the AICE Symposium on Preparation of Nuclear Fuels, Salt Lake City, UT, 1967.

5. A. S. Davidson, T. L. J. Moulding, Manufacture of the First Fuel Element Charge for the Prototype Fast Reactor. IAEA-SM-173/64, Internationa 1 Atomic Energy Agency, Vienna, 1974. 
.

.

. 
BIBLIOGRAPHY

*American Nuclear Society Transactions. (Summaries of LWR fuel irridation performance, fuel development and production, etc., 1974-1976.)

*Atomic Energy Law Reports, Appendix P. 10 CFR 50, Commerce Clearing House, Inc., 1975.

*Ibid., Appendix Q, 1974.

D. M. Bishop, W. E. Baily, Nondestructive Examination of Plutonium Recycle Fuel Rods Irradiated to 30,000 MWd/A. NEDO-12552, General Electric Company, San Jose, CA, 1974.

${ }^{\star}$ C. L. Brown, L. C. Davenport, and D. P. Oden, "Plutonium Fuel Technology, Part III: Nuclear Criticality Safety Considerations in LWR (Pu, U)O ${ }_{2}$ Fue 1 Fabrication". Nuclear Technology, 18:109-119, 1973.

*J. B. Burnham, D. E. Deonigi, L. G. Merker, Comparative Costs of Oxide Fuel Elements. BNWL-273, Vols. 1-3, Battelle, Northwest Laboratories, Richland, WA, 99352, 1966.

C. S. Cadwell and K. H. Puechl, "Plutonium Uranium Dioxide Powder and Pellet Fuel Manufacture". CONF-671005, presented at the Nuclear Metallurgy Conference, Apollo, PA, 1968.

*Criteria for Design of Plants for Manufacture of Mixed 0xide (U-Pu) Fuels. ANSI N287-1976, Draft \#8, Ju1y 1976.

*A. S. Davidson, T. L. J. Moulding, Manufacture of the First Fuel Element Charge for the Prototype Fast Reactor. IAEA-SM-173/64, International Atonic Energy Agency, Vienna, 1974.

P. Deramaix, H. Bariot, C. Vandenberg, "Experience of Belgonucleaire on Plutonium Recycle Configurations in LWR's". AED-Conf--74-571-011, presented to Societe Belge pour 1'Industrie Nucleaire, Brussels, Belgium, 1974.

*Final Generic Environmental Statement on the Use of Recycle Plutonium in Mixed Oxide Fuel in Light Water Cooled Reactors (GESMO). NUREG-0002, Vol. 3, National Technical Information Service, Springfield, VA 22161, 1976.

*A. J. Flipot, J. M. Leblanc, I. Lafontaine, "Plutonium Fuel Development and Production". American Nuclear Society Transactions, Vol. 21.

*P. Funke, W. Lins, V. W. Schneider, Production of Mixed-0xide Fuel for Fast Reactors. IAEA-SM-173/21, International Atomic Energy Agency, Vienna, 1974.

*General Design Criteria Plutonium Facilities. Appendix 6301, Part II, Atomic Energy Commission, 1974.

J. Haley, EEI-Westinghouse Plutonium Recycle Demonstration Program Progress Report. WCAP-4167-2, Westinghouse Electric Corporation, Pittsburgh, PA, 1971. 


\section{BIBLIOGRAPHY (continued)}

*J. P. Keenan, S. Goldsmith, D. R. de Halas, Fabrication and Irradiation, Factors Influencing Plutonium Recycle Economics. BNWL-SA-1079, Battelle, Northwest Laboratories, Richland, WA 99352, 1967.

S. Bataller, et al., "Mixed Uranium--Plutonium Oxide Fuel Fabrication for Rapsodie". CONF-671005, presented at the Nuclear Metallurgy Conference, Phoenix, AZ, 1968.

*Recycle Fuels Plant, License Application. AEC Docket No. 70-1432, Westinghouse Electric Corporation, Pittsburgh, PA, July 13, 1973.

R. I. Robertson and I. H. Gibson, "Production and Performance of Plutonium Enriched Thermal Reactor Fuel". CONF-731004, presented at the International Conference on Fuel Performance, London, U.K., October 15, 1973.

S. E. Smith, J. S. Broadley, F. Brown, and W. C. L. Kent, "Development of Large-Scale Manufacturing Process and Plant for Plutonium Fast Reactor Fuel". Proceedings of the Third International Conference on the Peaceful Uses of Atomic Energy, Geneva, Switzerland.

*S. E. Smith and P. A. White, "Process and Plant Development for a Large Scale Plutonium Fuel Element Manufacturing Facility". Proceedings of the AICE Symposium on Preparation of Nuclear Fuels, Salt Lake City, UT, 1967.

P. A. F. White, "Plutonium Fuel Element Production". Nuclear Engineering, May 1964.

* Primary references used. 
APPENDIX A

QUESTIONNAIRE FOR FUEL SUPPLIER SURVEY 
$\therefore$ 


\section{FORM A}

\section{GENERAL OPINIONS}

1. In general, the process and materials handling equipment suitable for use in a high volume ( $\approx 700 \mathrm{MT} / \mathrm{yr}$ ) LWR mixed-oxide fuel manufacturing plant:
a. Is already well developed
b. Needs minor additional development
c. Needs major additional development

2. The following process and materials handling equipment items need the most development effort (Category Type 1.C above):

3. What approach should be taken to the design and development of Category 1.C equipment?

a. Design and develop new equipment

Yes No

b. Retrofit and adapt existing equipment used in $\mathrm{UO}_{2}$ plants and other industries

c. Other

4. Equipment manufacturers are interested in providing special mixed-oxide fuel production equipment:

a. If an adequate market is established

$\underline{\text { Yes }} \quad \underline{\text { No }}$

b. If additional design and development is paid for by the customer 
GENERAL OPINIONS (cont'd)

c. We plan to utilize our own designs

Yes No

d. Other

5. The general design philosophy on equipment used in mixed-oxide fuel plants:

a. For $\mathrm{PuO}_{2}$ powder it should be:

b. For $\mathrm{UO}_{2}-\mathrm{PuO}_{2}$ powder it should be:

c. For $\mathrm{UO}_{2}-\mathrm{PuO}_{2}$ pellets it should be:

d. For fuel rods it should be:

e. For fuel assemblies it should be:

6. General comments are:

7. Qualifying statements on input are:

(PLEASE ADD SHEETS IF ADDITIONAL WRITING SPACE IS NEEDED) 


\section{FORM B}

EQUIPMENT "STATE-OF-ART" OPINION"

ASSUMED

PROCESS STEP

RECEIVING $\mathrm{PuO}_{2}$

RECEIVING $\mathrm{UO}_{2}$

BLENDING POWDERS

MILLING

PRESLUG PRESS

GRANULATE

SIZE CLASSIFY

PELLET PRESS

SINTER

GRIND OD

DRY

DIM. CHECK \& MOIST.

ANAL.

ROD LOAD \& DECON.

WELD CAP

PRESSURIZE \& SEAL WELD (IF DONE)

LEAK TEST

$X$-RAY

GAMMA SCAN

VISUAL INSP.

WEIGH

CLEAN

AUTOCLAVE (IF DONE)

ASSEMBLY

FINAL INSP.

WEIGH \& PKG.

*RATING CATEgORY

S = SATISFACTORY, OK AS IS, MAY REQUIRE MINOR DESIGN AND DEVELOPMENT

$U$ = UNSATISFACTORY, NEEDS MAJOR REDESIGN AND DEVELOPMENT
MATERIALS HANDLING EQUIPMENT (TRANSFER TO NEXT PROCESS STEP)

\begin{tabular}{|c|c|c|c|c|c|}
\hline \multicolumn{3}{|c|}{ PROCESS EQUIPMENT } & \multicolumn{3}{|c|}{$\begin{array}{l}\text { MATERIALS HANDLING EQUIPMENT } \\
\text { (TRANSFER TONEXTPROCESS STEP) }\end{array}$} \\
\hline $\begin{array}{l}\text { FUNCTION- } \\
\text { ABILITY }\end{array}$ & $\begin{array}{l}\text { MAINTAIN- } \\
\text { ABILITY }\end{array}$ & $\begin{array}{c}\text { CLEANUP } \\
\text { REPLACEMENT } \\
\text { RePLe }\end{array}$ & $\begin{array}{l}\text { FUNCTION- } \\
\text { ABILITY }\end{array}$ & $\begin{array}{l}\text { MAINTAIN- } \\
\text { ABILITY }\end{array}$ & $\begin{array}{c}\text { CLEANUP \& } \\
\text { REPLACEMENT }\end{array}$ \\
\hline & & & & & \\
\hline & & & & & \\
\hline & & & & & \\
\hline & & & & & \\
\hline & & & & & \\
\hline & & & & & \\
\hline & & & & & \\
\hline & & & & & \\
\hline & & & & & \\
\hline & & & & & \\
\hline & & & & & \\
\hline & & & & & \\
\hline & & & & & \\
\hline & & & & & \\
\hline & & & & & \\
\hline & & & & & \\
\hline & & & & & \\
\hline & & & & & \\
\hline & & & & & \\
\hline & & & & & \\
\hline & & & & & \\
\hline & & & & & \\
\hline & & & & & \\
\hline & & & & & \\
\hline & & & & & \\
\hline
\end{tabular}


OPINION ON TYPES OF EQUIPMENT AND REMOTENESS OF

OPERATIONS THAT SHOULD BE USED

(PLACE " $X$ " IN MOST PREFERABLE MODES)

ASSUMED PROCESS STEP

RECEIVING $\mathrm{PuO}_{2}$ RECEIVING $\mathrm{UO}_{2}$ BLENDING POWDERS MILLING

PRESLUG PRESS GRANULATE SIZE CLASSIFY PELLET PRESS SINTER NGRIND OD DRY

DIM, CHECK \& MOIST.

\section{WELD CAP}

PRESSURIZE \& SEAL WELD (IF DONE)

LEAK TEST

X-RAY

GAMMA SCAN

VISUAL INSP

WEIGH

CLEAN

Autoclave (IF DONE) ASSEMBLY FINAL INSP. WEIGH \& PKG

\begin{tabular}{|c|c|c|c|c|c|}
\hline \multicolumn{3}{|c|}{ TYPES OF PROCESS EQUIPMENT } & \multicolumn{3}{|c|}{ REMOTENESS OF OPERATIONS } \\
\hline ВАTCH & CONTINUOUS & ВОTн & MANUAL & SEMI-MECHANIZED & FULLY.MECHANIZED \\
\hline & & & & & \\
\hline & & & & & \\
\hline & & & & & \\
\hline & & & & & \\
\hline & & & & & \\
\hline & & & & & \\
\hline & & & & & \\
\hline & & & & & \\
\hline & & & & & \\
\hline & & & & & \\
\hline & & & & & \\
\hline & & & & & \\
\hline & & & & & \\
\hline & & & & & \\
\hline & & & & & \\
\hline & & & & & \\
\hline & & & & & \\
\hline & & & & & \\
\hline & & & & & \\
\hline & & & & & \\
\hline & & & & & \\
\hline & & & & & \\
\hline & & & & & \\
\hline & & & & & \\
\hline & & & & & \\
\hline
\end{tabular}




\section{DISTRIBUTION}

No. of

Copies

OFFSITE

A. A. Churm

ERDA Chicago Patent Group

9800 South Cass Avenue

Argonne, IL 60439

ERDA Albuquerque Operations Office

P.0. Box 5400

Albuquerque, NM 87115

ERDA Chicago Operations Office 9800 South Cass Avenue

Argonne, IL 60439

J. L. Liverman, Director

ERDA Division of Biomedical and Environmental Research Washington, DC 20545

N. F. Seivering, Asst. Admin. ERDA Division of International Affairs

Washington, DC 20545

R. W. Roberts, Asst. Admin. ERDA Nuclear Energy

Washington, DC 20545

Chief, Fuel Recycle Branch

ERDA Division of Reactor

Development Demonstration

Washington, DC 20545

H. E. Lyon

ERDA Division of Safeguards and Security

Washington, DC 20545

G. W. Cunningham, Director

ERDA Division of Waste Management

Production and Reprocessing

Washington, DC 20545
No. of

Copies

OFFSITE

G. Bradley

ERDA Division of Waste Management Production and Reprocessing

Washington, DC 20545

K. Burson

ERDA Division of Waste Management Production and Reprocessing Washington, DC 20545

P. Horgroian

ERDA Division of Waste Management Production and Reprocessing Washington, DC 20545

C. Kuhlnan

ERDA Division of Waste Management Production and Reprocessing Washington, DC 20545

H. McVey

ERDA Division of Waste Management Production and Reprocessing Washington, DC 20545

G. Pleat

ERDA Division of Waste Management Production and Reprocessing Washington, DC 20545

D. Spurgeon

ERDA Division of Waste Management Production and Reprocessing Washington, DC 20545

ERDA Idaho Operations Office 550 2nd Street

Idaho Falls, ID 83401

ERDA Oak Ridge Operations Office P. 0. Box $E$

Oak Ridge, TN 37830 
No. of

Copies

2 ERDA San Francisco Operations Office

1333 Broadway, Wells Fargo Building

Oakland, CA 94616

University of California

Lawrence Livermore Laboratory

P. 0. Box 808

Livermore, CA 94550

T. B. Hindman, Jr., Director

Fuel Cycle Project office

ERDA Savannah River Operations Office

P. 0. Box "A"

Aiken, SC 29801

Norman Hook

ERDA Savannah River Operations Office

P. 0. Box "A"

Aiken, SC 29801

N. Stetson, Manager

ERDA Savannah River Operations Office

P. 0. Box "A"

Aiken, SC 29801

27 ERDA Technical Information Center

F. J. Kierman, Eastern Regional Manager

Energy Systems

Aerojet, Energy Conversion Company

1120 Connecticut Avenue, NW

Suite 1050

Washington, DC 20036

F. H. Anderson, General Manager

Allied Chemical Corporation

550 Second Street

Idaho Falls, ID 83401
No. of

Copies

A. E. Schubert, President

All ied-General Nuclear Services

P. 0. Box 847

Barnwel1, SC 29812

A. K. Williams

Allied-General Nuclear Services

P. 0. Box 847

Barnwel1, SC 29812

J. A. Kyger, Assoc. Director

Argonne National Laboratory

9700 South Cass Avenue

Argonne, IL 60439

L. M. Richards, Coordinator

Nuclear Comm. Deve.

Atlantic Richfield Company

Box 2679 - TA

Los Angeles, CA 90071

R. H. Ihde, Manager

Contracts and Marketing

Babcock and Wilcox

P. 0. Box 1260

Lynchburg, VA 24505

J. M. Batch, Director

Battelle-Columbus Laboratories

505 King Avenue

Columbus, $\mathrm{OH} 43201$

S. M. Nealey

Battelle-Human Affairs Research Center

4000 N.E. 41 st Street

Seattle, WA 98105

J. E. Rasmussen, Director

Battelle-Human Affairs Research Center

4000 N.E. 41 st Street

Seattle, WA 98105

C. R. Schuller

Battelle-Human Affairs Research Center

4000 N.E. 41 st Street

Seattle, WA 98105 
No. of

Copies

Richland L. Grant, Director Nuclear Projects

Boeing Engineering and Construction Division

P. 0. Box 3707

Seattle, WA 98124

M. I. Naparstek, Manager

Proposals

Burns and Roe, Industrial

Services Corporation

P. 0. Box 663

Paramus, NJ 07652

C. K. Anderson

Combustion Engineering

Nuclear Power Division

1000 Prospect Hill Road

Windsor, CT 06095

G. R. Corey, Vice Chairman

Commonwealth Edison Company

P. 0. Box 767

Chicago, IL 60690

L. E. Smith

Carolina Power and

Light Company

P. 0. Box 1551

Raleigh, NC 27602

M. G. Britton, Manager

Technical Liaison

Corning Glass Works

Corning, NY 14830

R. G. Cross

DBM Corporation

1920 Alpine Avenue

Vienna, VA 22180

J. Carp, Director

Energy Policy

Edison Electric

90 Park Avenue

New York, NY 10016
No. of

Copies

10 C. H. Ice, Director

SRL

E. I. duPont de Nemours and Company

Aiken, SC 29801

S. J. Beard

Exxon Nuclear Company, Inc.

777 - 106th Avenue, N.E.

Bellevue, WA 98009

R. L. Dickeman, President

Exxon Nuclear Company, Inc.

777 - 106th Avenue, N.E.

Bellevue, WA 98009

A. H. Hines, Jr., President Florida Power Corporation

P. 0. Box 14042

St. Petersburg, FL 33733

Dr. Uhrig

Florida Power and Light Company

P. 0. Box 013100

Miami, FL 33101

John Shefcik

General Atomic Company

P. 0. Box 81608

San Diego, CA 92138

R. G. Barnes

Genera1 Electric Company

175 Curtner Avenue

San Jose, CA 95125

K. Bowlman

General Electric Company

175 Curtner Avenue

San Jose, CA 95125

B. H. Cherry, Manager

Fuel Resources

GPU Services Corporation

260 Cherry Hill Road

Parsippany, NJ 07054 
No. of

Copies

W. A. Kalk, Manager

Nuclear Power Systems

Holmes and Narver, Inc.

400 E. Orangethorpe Avenue

Anaheim, CA 92801

H. M. Agnew, Director

Los Alamos Scientific Laboratory

P. 0. Box 1663

Los Alamos, NM 37545

F. W. Lewis, President

Middle South Utilities, Inc.

P. 0. Box 61005

New Orleans, LA 70161

Martin Binstock

Kerr-McGee Nuclear Corporation

Kerr-McGee Building

Oklahoma City, OK 73102

Kenneth Street, Assoc. Director

Livermore Radiation Laboratories

P. 0. Box 808

Livermore, CA 94550

W. T. Cave, Director

Monsanto Research Corporation

Mound Laboratory

P. 0. Box 32

Miamisburg, OH 45332

George Stukenbroeker

$\mathrm{NL}$ Industries

P. 0. Box 928

Barnwell, SC 29812

G. K. Rhode, VP

Engineering

Niagara Mohawk Power Corporation

300 Erie Boulevard, West

Syracuse, NY 13202

R. Cunningham

NRC Nuclear Materials Safety and Safeguards

Washington, DC 20545
No. of

Copies

Saul Levine, Deputy Director

NRC Research

Washington, DC 20545

R. W. Deuster, President

Nuclear Fuel Services, Inc.

6000 Executive Blvd.

Rockville, MD 20952

W. J. Wilcox, Technical Director

Oak Ridge Gaseous Diffusion Plant

Oak Ridge, TN 27820

Herman Postma, Director

Oak Ridge National Laboratory

P. 0. Box $X$

Oak Ridge, TN 37830

C. A. Hirenda, Director

Marketing

Proposal Management, Inc.

121 N. Orionna Street

Philadelphia, PA 19106

R. D. Oldenkamp

Rockwell International

Atomics International Division

8900 De Soto Avenue

Canoga Park, CA 91304

R. 0. Williams, VP

Rockwell International

Rocky Flats Plant

P. 0. Box 464

Golden, C0 80401.

Science Applications, Inc.

1680 Hanover Street

Palo Alto, CA 94303

R. C. Adkins, Technica1 Representative

NUSAC

7926 Jones Branch Drive

McClean, VA 22101 
No. of

Copies

Ray Hoskins

Tennessee Valley Authority

217 Electric Power Board Bldg.

Chattanooga, TN 37401

K. Vickers

Thraeger Tech.

110 S. Euclid Avenue

Pasadena, CA 91101

S. M. Stoller

The S. M. Stoller Corp.

Western Reprocessors

1250 Broadway

New York, NY 10001

Claude Stevens

Virginia Electric Power Co.

Nuclear Fuel Service Dept.

512 Franklin Building

P. 0. Box 26666

Richmond, VA 23261

J. F. Bader, Manager

Westinghouse Electric Corporation

Plutonium Recycle Fuel Programs

P. 0. Box 355

Pittsburgh, PA 15230

Wende 11 Johnson, VP

Yankee Atomic Electric Company

20 Turnpike Road

Westboro, MA 01581

\section{ONSITE}

2 ERDA Richland Operations office

H. E. Ransom

P. A. Craig

N. T. Karagianes

2 Rockwe 11 Hanford Operations

H. H. Hopkins

J. E. Kinzer
No. of

Copies

3 Hanford Engineering Development Laboratory

M. J. Barr

R. E. Dah1, Jr.

R. B. McCord

60 Battel1e-Northwest

L. E. Addison

R. P. Allen

G. S. Allison

T. W. Ambrose

W. J. Bailey

5 D. E. Blahnik

D. W. Brite

C. L. Brown

L. M. Browne

L. L. Burger

N. E. Carter

D. B. Cearlock

E. D. Clayton

W. J. Coleman

J. W. Finnigan

R. M. Fleischman

M. D. Freshley

J. C. Fox

S. Goldsmith

A. J. Haverfield

E. R. Irish

J. H. Jarrett

W. S. Kelly

R. S. Kemper

D. H. Lester

R. C. Lloyd

R. P. Marshall

E. T. Merri11

I. C. Nelson

R. D. Nelson

J. F. Nesbitt

D. F. Newman

J. M. Nielson

R. E. Nightingale

D. R. Oden

D. E. O1esen

G. B. Parker 
No. of

Copies

L. T. Pedersen

A. M. Platt

W. E. Reardon

F. R. Reich

R. D. Scheele

L. C. Schwendiman

C. L. Simpson

J. L. Swanson

C. M. Unruh

H. H. Van Tuy 1

L. L. Wendell

R. D. Widrig

M. G. Zimmerman

Technical Information (5)

Technical Publications (1) 